\title{
Value Chain Analysison Processing Cardava Banana Chips In The Philippines: Luzon Case
}

\author{
Gigi B. Calica, PhD*, Karen R. Lingbawan \\ Senior Science Research Specialist \\ Philippine Center for Postharvest Development and Mechanization (PHilMech) \\ CLSU Compound, Science City of Munoz, Nueva Ecija, Philippines 3120 \\ Science Research Analyst 1 \\ Philippine Center for Postharvest Development and Mechanization (PHilMech) \\ CLSU Compound, Science City of Munoz, Nueva Ecija, Philippines 3120
}

\begin{abstract}
:
The study aimed to provide relevant information in terms of costs and income so that more people can be enticed to go into business of banana production and processing. This was conducted in the Philippines particularly in Luzon island. Value chain and descriptive analyses were used in the data processing.

Research results showed that the chains for the fresh cardava to wet market and to banana chips chains involved six to eight marketing actors namely: the farmer, consolidator, trucker, wholesaler/trader or wholesaler/retailer, processor, distributor, and retailer and the consumer. All activities from the farm to the market were manually done which resulted to more or less five days to deliver the commodity from the farm to the end user.

The processor received the highest gross margin share of 88.59 percent followed by wholesaler/retailer of banana chips getting around 6.25 percent share of gross margin. The farmer, agent/consolidator and wholesaler/retailer received 2.40 percent, 1.49 percent and 1.27 percent, respectively.

In terms of costs, the processor incurred the highest at $\mathrm{P} 4.25$ per $\mathrm{kg}$, the farmer at $\mathrm{P} 4.16$ per $\mathrm{kg}$ and the agent/consolidator at P2.83 per kg, both wholesaler/retailer for the fresh and processed products incurred lower costs than the other actors. Regarding income, chips wholesaler/retailer received the highest at P14.91 per kg; the processor at P6.26 per kg, and the wholesaler/retailer of fresh cardava, the farmer and the agent/consolidator received low income due to the low price of the commodity which was dependent on its quality.

Fertilizer application and use of postharvest tools to improve quality of produce was recommended to the farmers to receive higher price.
\end{abstract}

Keywords: fresh cardava banana chain, cardava banana, gross margins, costs, net income, banana chips chain, chain actors

\section{Introduction}

Banana stands out as the most important fruit crop in the Philippines, constituting a significant portion in the country's export revenue. Among the many banana cultivars grown throughout the country, cardava banana or locally known as saba (Musa balbisiana) is considered as one of the leaders in terms of production and trade. Processed products derived from saba are gaining wide acceptance both in the domestic and international market.

Banana is also a crop of social importance. It is an important source of food in the rural areas where saba banana, in particular, is often used to extend, supplement or substitute staple food such as rice and corn.

The strength of the banana industry lies on the big hectarage, which is a little more than half $(53.8 \%)$ of the total land area of the country planted to fruits $(621,861 \text { has })^{[1]}$. The country is also blessed with favorable climate, well suited for growing bananas all year round. There are already existing banana cultivars accepted in the domestic and export markets. The major cultivars are cavendish and señorita for the fresh export market, cardava 
for processed products (chips and crackers), lakatan, bungolan, latundan, and señorita for fresh local market.

Cardava, also known as saba banana in the Philippines has been traditionally grown for local market. In fact, according to a report of Bureau of Agricultural Research (BAR) ${ }^{[2]}$ in 2009, cardava is the world's fourth most important staple next to rice, corn, and wheat. However, Philippine's cardava has recently captivated the international market because of its nutritional value and versatility of use. Cardava is the specific variety of banana which is processed into banana chips.

Cardava grows to as tall as 20 feet; fruit is angular; has thick peel that is green when unripe, yellow when ripe; flesh is white when ripe; gestation period is 15 to 16 months. Cardava or saba has a large angular fruit with a white and sweet starchy flesh that makes it ideal for cooking. The saba plant's pseudostem is robust and grows taller than the dessert cultivars, producing about 8 suckers per mat at harvest. Its fruit, however, has a longer gestation period at 150 to 180 days after flowering. The plant's potential yield is 26 to 28 $\mathrm{kg}$ per bunch with one bunch containing up to 16 hands, each hand having 12 to 20 fingers. One fruit or finger is 8 to $13 \mathrm{~cm}$ long and 2.5 to $5.5 \mathrm{~cm}$ in diameter ${ }^{[3]}$.

The growth potential for banana processed products remains high. The country has still a large area of land suited for banana production while its population growth rate remains above 2 percent annually. With more effort to disseminate relevant information, more people can be enticed to go into business of banana production and processing ${ }^{[4]}$.

This paper discussed the chain on fresh cardava banana from Isabela to the processing of chips in Pangasinan for the local market. Further, this identified the different actors involved and their roles in the chain as well as their gross margins and income received and the costs incurred by each participating actor.

\section{Materials and Methods Data Collection}

In the country, particularly in the island of Luzon, Isabela was one of the top cardava producing provinces and Pangasinan was a major market for the commodity where some small scale processors operate were identified as study areas.

Primary data collection was done by conducting surveys or interviews, focus group discussions (FGD) and key informant interviews. Interviews through phone calls were also conducted for key informant. A structured questionnaire was prepared for the face-to-face interview.

\section{Methods of Analyses}

Data collected from the key informant interview to farmers/growers, traders and processors were analyzed using descriptive and value chain analyses with the aid of SPSS (Statistical Package for Social Sciences) computer software. Observation on the execution of each activity done by each actor was also done.

\section{Results And Discussion \\ Value chain mapping}

Two chains were observed in the area in selling fresh cardava banana from the farmer up to the end consumer. Figure 1 shows two routes: farmer to the market chain, fresh cardava as the product and farmer to the processor chain, banana chips as the product. The market observed was Urdaneta Market located in Pangasinan.

Moreover, service providers were engaged in the operation of the chains. These were identified as the input providers for the requirements of the farmers in producing the crop, financing institutions which assisted the different actors in times of short of finances and transporters who provided the equipment needed in delivering the goods from the production to the marketing areas. It was observed that the chain for the fresh cardava to wet market involved six to seven marketing actors namely: the farmer, consolidator, trucker, wholesaler/trader or wholesaler/retailer, retailer and the consumer. Each of the actors had his own functions in the chain. The farmer in Isabela was the one producing the fresh cardava banana which would be bought and assembled by the consolidator for around two to three days. A truckload of fresh cardava bananas would be transported by the consolidator to the wholesaler in the market place in Pangasinan where the wholesalers from the different municipalities got their supply for distribution to the retailers at their respective areas such as Ilocos (Figures 1 and 2).

Meanwhile, the chain for the fresh cardava to the banana chips processor involved eight actors. Additional three actors in the above chain were identified which were the banana chips processors, distributor and the chips wholesaler/retailer. The processor sourced out his supply of fresh banana from the wholesaler/retailer in the market and processed them into banana chips. Banana chips were 
delivered to the distributors who were in charge of providing the wholesaler/retailers whom consumers got his demand of banana chips.

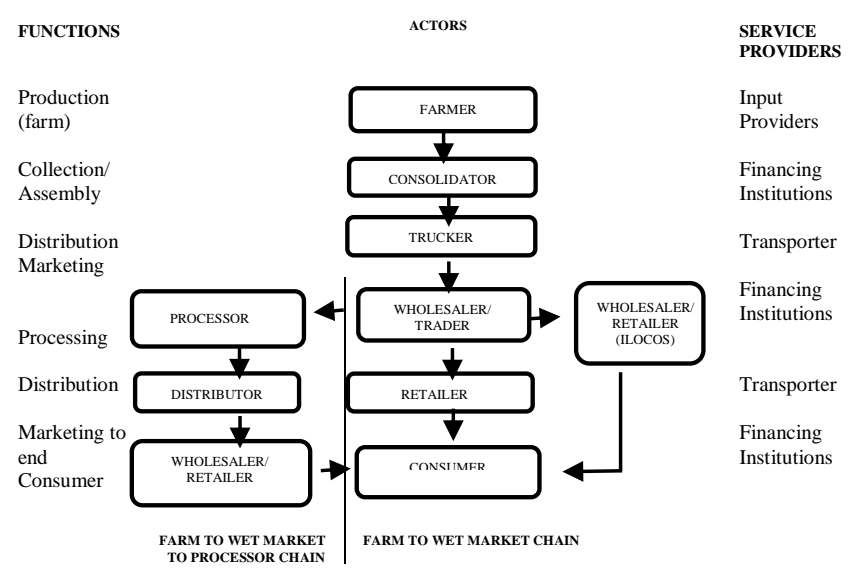

Figure 1. Chain map of Isabela cardava banana to Pangasinan market in fresh and banana chips products, 2014

Figure 2 describes the handling route of the fresh cardava banana from the farm to the market. The condition of the farm and its distance from the consolidator's place were also defined. Note that all activities from the farm to the market were manually done. Moreover, to visualize the situation of the commodity during transport, travel time and distances were revealed per stage. More or less five days would be spent to deliver the commodity from the farm to the end user.

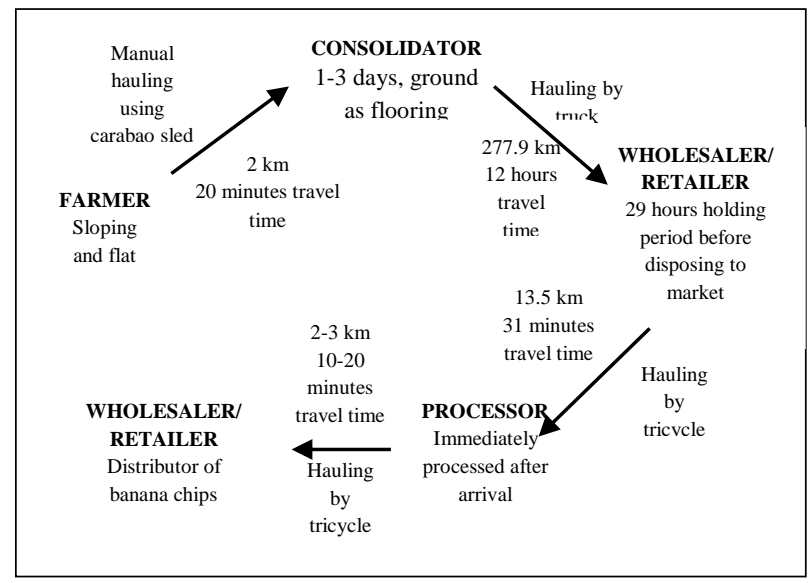

Figure 2. Handling route of fresh cardava banana from Isabela to Pangasinan, Luzon, Philippines, 2014

\section{Gross margins, costs and net income}

Since the actors involved in the fresh cardava chain was the same before the banana chips processor, discussion onwards was for the two chains (fresh cardava and banana chips) treated as one. Moreover, trucker and distributor were not included in the cost and net income computation because their services were paid by the consolidator and the processor.

From Isabela farm to Urdaneta, Pangasinan market up to the banana chips consumer chain, the value of the final product (banana chips) was around P240 per kg. The distribution of the gross margins among the different actors showed that processor received the highest gross margin share of 88.59 percent of the total value followed by wholesaler/retailer of banana chips getting around 6.25 percent share of gross margin. The remaining amount was shared among the farmer, agent/consolidator and wholesaler/retailer who received 2.40 percent, 1.49 percent and 1.27 percent, respectively (Table 1).

Table 1. Gross margin shares of the different chain actors in processing fresh cardava banana to banana chips, Isabela to Pangasinan, per kilogram, 2014

\begin{tabular}{|l|c|c|c|c|}
\hline \multirow{2}{*}{$\begin{array}{l}\text { MARKET } \\
\text { PLAYER }\end{array}$} & $\begin{array}{l}\text { SELLING } \\
\text { PRICE }\end{array}$ & $\begin{array}{l}\text { BUYING } \\
\text { PRICE }\end{array}$ & \multicolumn{2}{|c|}{ GROSS MARGIN } \\
\cline { 2 - 5 } & PhP/kg & PhP/kg & $\begin{array}{l}\text { Amount } \\
(\text { PhP/kg) }\end{array}$ & $\begin{array}{c}\text { Share } \\
(\%)\end{array}$ \\
\hline Farmer & 5.75 & - & 5.75 & 2.40 \\
\hline $\begin{array}{l}\text { Consolidator/ } \\
\text { Trader }\end{array}$ & 9.33 & 5.75 & 3.58 & 1.49 \\
\hline $\begin{array}{l}\text { Wholesaler/ } \\
\text { Retailer }\end{array}$ & 12.38 & 9.33 & 3.04 & 1.27 \\
\hline Chips Processor & 225.00 & 12.38 & 212.63 & 88.59 \\
\hline $\begin{array}{l}\text { Chips Wholesaler/ } \\
\text { Retailer }\end{array}$ & 240.00 & 225.00 & 15.00 & 6.25 \\
\hline End user & & $\mathbf{2 4 0 . 0 0}$ & $\mathbf{2 4 0 . 0 0}$ & $\mathbf{1 0 0 . 0 0}$ \\
\hline
\end{tabular}

$1 \mathrm{USD}=\mathrm{P} 44.78$

Processors got the large chunk of the gross margin shares because his cost of production was fixed per batch of operation. Wholesale/retailers of banana chips were recorded the second highest recipient of gross margin shares because they charged higher margin to cover up their expected losses they would incur in their operation such as rejects and unsold packs. On the other hand, farmers, consolidators and wholesale/retailer of fresh saba received the small chunks of the gross margin shares due to the quality of the commodity (in terms of roundness, size and freshness) they offered the market.

Examining the costs among the actors of the chain, processor incurred the highest cost which was at P4.25 per $\mathrm{kg}$, followed by the farmer at $\mathrm{P} 4.16$ per $\mathrm{kg}$ and the agent/consolidator at $\mathrm{P} 2.83$ per kg. On the other hand, both wholesaler/retailer for the fresh and processed products incurred lower costs than the other actors, i.e. P0.31 and P0.10 per kg, respectively (Table 2).

High costs were incurred by the processor and farmers because aside from buying the raw 
materials in the market, the processor was doing several activities such as peeling, slicing, cooking, packaging and distribution which required more labor. On the other hand, farmer had to do the cultural practices of producing saba as well as the postharvest activities (on and off farm hauling) to reach the consolidators' place. It was observed that the processor and the farmer had more activities than the other actors in the chain.

In terms of income, chips wholesaler/retailer received the highest income at $\mathrm{P} 14.91$ per $\mathrm{kg}$ and next was the processor at P6.26 per kg because of the fixed costs incurred per batch. Wholesaler/retailer of fresh cardava, the farmer and the agent/consolidator received low income due to the low price of the commodity which was dependent on its quality.

Now let us look how these actors in the whole chain share in terms of costs and net income. On the costs sharing, processor allotted around 11.56 percent, farmer gave 11.32 percent, while agent/consolidator, wholesaler/retailer and chips wholesaler/retailer apportioned 7.70 percent, 0.84 percent, and 0.27 percent, respectively. For the net income shares, chips wholesaler/retailer gave the highest at 40.56 percent, followed by the processor with 17.03 percent, wholesaler/retailer at 5.98 percent, farmer with 4.33 percent and agent/consolidator with 0.41 percent.

Table 2. Cost and net income shares of the different chain actors in processing fresh cardava banana to banana chips, Isabela to Pangasinan, per kilogram, 2014

\begin{tabular}{|l|c|c|c|c|c|c|}
\hline $\begin{array}{l}\text { COSTS/ } \\
\text { PERCEN } \\
\text { TAGE }\end{array}$ & $\begin{array}{l}\text { FAR } \\
\text { MER }\end{array}$ & $\begin{array}{l}\text { AGENT/ } \\
\text { CONSOLI } \\
\text { DATOR }\end{array}$ & $\begin{array}{l}\text { WHOLES } \\
\text { ALER/ } \\
\text { RETAILE } \\
\mathbf{R}\end{array}$ & $\begin{array}{l}\text { PROC } \\
\text { ESSOR }\end{array}$ & $\begin{array}{l}\text { BANAN } \\
\text { A CHIPS } \\
\text { WHOLE } \\
\text { SALER/ } \\
\text { RETAIL } \\
\text { ER }\end{array}$ & $\begin{array}{l}\text { TOTA } \\
\text { L }\end{array}$ \\
\hline Roles & $\begin{array}{l}\text { Produ } \\
\text { ction, } \\
\text { harve } \\
\text { sting, } \\
\text { on } \\
\text { and } \\
\text { off } \\
\text { farm } \\
\text { hauli } \\
\text { ng }\end{array}$ & $\begin{array}{l}\text { Consolidat } \\
\text { ing, piling } \\
\text { and } \\
\text { trucking } \\
\text { to market }\end{array}$ & $\begin{array}{l}\text { Dipping, } \\
\text { packagin } \\
\text { g and } \\
\text { retailing }\end{array}$ & $\begin{array}{l}\text { Peelin } \\
\text { g, } \\
\text { slicing } \\
\text { cookin } \\
\text { g, } \\
\text { packa } \\
\text { ging } \\
\text { transp } \\
\text { ort }\end{array}$ & $\begin{array}{l}\text { Distribu } \\
\text { tion and } \\
\text { retailing } \\
\text { banana } \\
\text { chips }\end{array}$ & \\
\hline $\begin{array}{l}\text { Costs, } \\
\text { PhP/kg }\end{array}$ & 4.16 & 2.83 & 0.31 & 4.25 & 0.10 & 218.56 \\
\hline $\begin{array}{l}\text { Net } \\
\text { Income, } \\
\text { PhP/kg }\end{array}$ & 1.59 & 0.15 & 2.20 & 6.26 & 14.91 & 21.33 \\
\hline $\begin{array}{l}\text { Cost } \\
\text { share, } \%\end{array}$ & 11.32 & 7.70 & 0.84 & 11.56 & 0.27 & 31.69 \\
\hline $\begin{array}{l}\text { Net } \\
\text { income } \\
\text { share, } \%\end{array}$ & 4.33 & 0.41 & 5.98 & 17.03 & 40.56 & 68.31 \\
\hline TOTAL & $\mathbf{1 5 . 6 5}$ & $\mathbf{8 . 1 1}$ & $\mathbf{6 . 8 2}$ & $\mathbf{2 8 . 5 9}$ & $\mathbf{4 0 . 8 3}$ & $\mathbf{1 0 0 . 0 0}$ \\
\hline 1USD = P44.78 & & & & & & \\
\hline
\end{tabular}

Starting off with the farmer, one $\mathrm{kg}$ of banana chips required around $11.94 \mathrm{~kg}$ of fresh cardava banana. For this particular volume, farmers spent for growing saba banana and postproduction costs, amounted to $\mathrm{PhP} 41.42$. The postharvest losses incurred by the farmers such as pre-harvest loss, detached and weight loss were valued and added to the costs of the farmers, resulting to a PhP49.64 total expenses. Selling the product at PhP68.63 the farmers had a net income of $\mathrm{PhP18.99}$. However, if the losses from the preharvest and detached would be able to addressed, net income of farmers would be increased by P6.33. Weight reduction was not included because naturally the commodity emits gases which impact the weight of the saba.

The consolidator/trader who bought the commodity from the farmer incurred postharvest loss of 4.71 percent due to weight loss from two days stocks accumulation piled in an open spot in his area, thus receiving net income of $\mathrm{PhP} 1.59$. No postharvest loss for the wholesaler/retailer was recorded because observations were not done on this level. However, all costs incurred by the actor in his/her trading activity were noted at PhP101.13 and a net income of PhP21.91.

For banana chips processor, costs incurred totaled to around $\mathrm{PhP} 164.30$ including the postharvest losses and the weight loss. Net income received amounted to $\mathrm{PhP60.70.} \mathrm{On} \mathrm{the} \mathrm{other}$ hand, the wholesaler/retailer of banana chips selling one $\mathrm{kg}$ spent around 225.09 and received $\mathrm{PhP} 14.91$ as net income.

Table 3. Value chain analysis for $1 \mathrm{~kg}$ cardava banana requirement of banana chips processing, from Isabela to Pangasinan, Luzon, Philippines, 2014

Table 3 presents the costs incorporating the postharvest losses incurred and income received by the different actors in processing one $\mathrm{kg}$ of banana chips in Pangasinan.

\begin{tabular}{|c|c|}
\hline ITEM & AMOUNT \\
\hline FARM & @ 11.94 kg \\
\hline Production cost, $\mathrm{P}$ & 18.86 \\
\hline Post production cost,P & 22.56 \\
\hline Pre-harvest loss & 5.98 \\
\hline Detached & 0.35 \\
\hline Weight loss & 1.89 \\
\hline Total & 49.64 \\
\hline Selling price & 68.63 \\
\hline Net Income & 18.99 \\
\hline CONSOLIDATOR/TRADER & $10.51 \mathrm{~kg}$ \\
\hline Buying Price & 68.63 \\
\hline Labor cost & 1.47 \\
\hline Trucking cost & 21.75 \\
\hline Loss (weight reduction) $(4.71 \%)$ & 4.62 \\
\hline Total & 96.46 \\
\hline Selling price & 98.05 \\
\hline
\end{tabular}

Gigi B. Calica, IJSRM Volume 07 Issue 01 January 2019 [www.ijsrm.in]

EM-2019-944 


\begin{tabular}{|c|c|}
\hline Net Income & 1.586 \\
\hline WHOLESALER/RETAILER & $9.94 \mathrm{~kg}$ \\
\hline Buying price & 98.05 \\
\hline Stall rental & 0.89 \\
\hline Labor cost & 1.39 \\
\hline Material cost & 0.80 \\
\hline Weight reduction & 3.61 \\
\hline Total & 101.13 \\
\hline Selling price & 123.04 \\
\hline Net Income & 21.91 \\
\hline PROCESSOR & $9.70 \mathrm{~kg}$ \\
\hline Buying price & 123.04 \\
\hline Material cost & 13.49 \\
\hline Direct labor cost & 7.40 \\
\hline Overhead expenses & 0.58 \\
\hline Transportation cost & 2.48 \\
\hline Packaging cost & 8.40 \\
\hline Loss (weight of peel) & 6.56 \\
\hline $\begin{array}{l}\text { Loss (weight of meat scraped with } \\
\text { the peel) }\end{array}$ & 0.74 \\
\hline Loss (weight reduction) (13\%) & 1.61 \\
\hline $\begin{array}{ll} & \text { Total } \\
\end{array}$ & 164.30 \\
\hline Selling price & 225.00 \\
\hline Net income & 60.70 \\
\hline WHOLESALER/RETAILER & $1 \mathrm{~kg}$ \\
\hline Buying price & 225.00 \\
\hline Stall rental & 0.09 \\
\hline Total & 225.09 \\
\hline Selling price & 240.00 \\
\hline Net income & 14.91 \\
\hline
\end{tabular}

actors, i.e. $\mathrm{P} 0.31$ and $\mathrm{P} 0.10$ per $\mathrm{kg}$, respectively. In terms of income of the actors involved in the chain, chips wholesaler/retailer received the highest income at P14.91 per $\mathrm{kg}$ and next was the processor at P6.26 per $\mathrm{kg}$ because of the fixed costs incurred per batch. Wholesaler/retailer of fresh cardava, the farmer and the agent/consolidator received low income due to the fluctuating price of the commodity which was dependent on its quality.

One $\mathrm{kg}$ of banana chips required around $11.94 \mathrm{~kg}$ of fresh cardava banana wherein farmers spent amounted to PhP41.42. The postharvest losses incurred by the farmers such as pre-harvest loss, detached and weight loss were valued and added to the costs of the farmers, resulting to a $\mathrm{PhP} 49.64$ total expenses. Selling the product at PhP68.63 the farmers had a net income of PhP18.99. However, if the losses from the pre-harvest and detached would be able to addressed, net income of farmers would be increased by P6.33. The consolidator/trader who bought the commodity from the farmer incurred postharvest loss of 4.71 percent due to weight loss from two days stocks accumulation piled in an open spot in his area, thus receiving net income of $\mathrm{PhP1.59}$. For the wholesaler/retailer all costs incurred in his/her trading activity were at $\mathrm{PhP} 101.13$ and a net income of $\mathrm{PhP} 21.91$. For banana chips processor, costs incurred totaled to around PhP164.30 and net income received amounted to PhP60.70. On the other hand, the wholesaler/retailer of banana chips selling one $\mathrm{kg}$ spent around 225.09 and received $\mathrm{PhP} 14.91$ as net income.

It is recommended that farmers should improve their crop management through fertilizer application and frequent weeding so as to improve the quality of the product to receive higher selling price. More so, improve the postharvest practices such as a tool for dehanding to prevent detached fingers.

\section{Acknowledgment}

The authors would like to thank Ms. Zeren Lucky L. Cabanayan, Ms. Maggie Mae N. Dulay and Ms. Joanne T. Ceynas who helped us gather the data and PHilMech for funding the study.

\section{References}

[1] Bureau of Agricultural Statistics. 2012. Quezon City P2.83 per $\mathrm{kg}$. On the other hand, both wholesaler/retailer for the fresh and processed products incurred lower costs than the other 
[2] BAR Research and Development Digest. 2009. The Future brightens for Philippine bananas Volume.11 No. 1. Diliman, Quezon City.

[3] Department of Agriculture. Undated. Cardava Banana Commodity Profile, Diliman, Quezon City

[4] Arturo A.S., Burgos, B. M. and Eusebio J. E. 2005. Analysis of Banana Processing and Their Support Environment in the Philippines.

[5] Calica, G.B., Lingbawan, K.R., and Dela Cruz, R.SM. 2014. Assessment on the Postharvest Handling Systems and Losses of Cardava Banana in the Philippines, Asian Journal of Postharvest and Mechanization (AJPM) Vol. 1 No.1., pp. $84-100$ 